the data on which the geological boundaries have been traced, and can thus judge where and how far these are conjectural. We are not aware of any other published maps where this confession has been so frankly made.

The pale yellows and greys adopted for the superficial deposits cover so much of each sheet as to show at once how large a part of the ground is occupied by them. The detrital material is traced up to its source upon the tablelands, and being of poor agricultural value its colour on the map shows where farming operations are least likely to be successful. Where observations by boring or otherwise have been made on the nature of the soil and subsoil these are marked on the spot by the requisite sign, and as the borings are numerous these indications abound all over the map.

During the progress of the work improvements have been made in the methods of surveying and also in the modes of expressing geological details on the maps. In the Brussels area, for example, besides the ordinary borings into the soil and subsoil, deeper borings have been made to ascertain the nature and succession of the strata underlying the uppermost deposits. Messrs. Rutot and Van den Broeck, two of the staff, have invented an ingenious instrument with which they can ascertain the nature of the formations down to a depth of even ro metres. By its means they have pierced below the subsoil in all directions, and have accurately traced out the areas of the younger deposits around Brussels. The results obtained by them at each boring are clearly engraved on the map; so that at numerous points all over the district the farmer, the water-engineer, the railwaycontractor, the quarryman, and others can learn precisely through what layers they must pass in any cutting or excavation beneath the surface. By another ingenious device, the section of each artesian well at Brussels is represented on the map beside the position of the well, and so clearly that the succession of rocks bored through may be taken in by the eye at once.

Each sheet of this detailed survey is so crowded with information that to those who have been accustomed only to the ordinary style of geological map-making it may at first seem a little confused. But if any one will take the least trouble he will soon find that the confusion is only in appearance. No maps have yet been published in any country giving so large an amount of accurate information with such clearness and precision, and where the actual facts are kept so clearly apart from inference. These sheets are not wall-maps to be looked at from a distance, but detailed maps to be closely studied in the hand. And they will well repay an attentive study. There is probably no national Geological Survey in any part of the world which may not find in them some useful hint or suggestion for its own improvement.

On completion of the detailed survey it is part of the original plan to prepare a smaller or wall-map like that of Dumont. But such a map is hardly needed; at least its preparation can well stand over until the whole country has been surveyed in detail by the methods so well conceived by M. Dupont. But besides the maps, the work of the Belgian Survey has included the preparation of ample explanations illustrative of the maps. Each sheet is intended to be accompanied with an "Explication" giving the detailed structure of the ground, descriptions of the rocks, natural sections, lists of fossils, and all the information required as supplementary to the geological maps. A number of these memoirs have already been printed. Each of them contains fundamentally three sections running $\mathrm{N}$. and $\mathrm{S}$. across the formations, which in Belgium have a general $\mathrm{E}$. and W. strike. These sections are described in detail, and full local references are given. The books are well printed, and the coloured plates of sections are excellent, while a novel attraction is given by the insertion into the text of coloured engraved sections of special localities.
None of the maps or explanations, though they have been ready for some time, have yet been published. They are to be seen, however, in some of the public libraries and museums in Europe. Belgium has every reason to be proud of them, and we trust that the delay in their publication will speedily be followed by the issue of the whole series now ready and by the completion of those in progress. It is impossible to over-estimate the practical utility of such a detailed survey in a country like Belgium. No time should be lost in pushing on and bringing to a conclusion a work which has been so admirably begun.

ARCH. GEIKIE

\section{THE THIRD INTERNATIONAL GEOLOGICAL CONGRESS}

$\mathrm{THE}$ third International Congress of Geologists, postponed last year on account of the spread of cholera in southern Europe, has just been held at Berlin. Each successive gathering has far surpassed its predecessors in numbers and in the representative character of its members, the numbers attending the meeting at Berlin being no fewer than 255. Of these of course the large majority were Germans, who mustered in all 163 . Italy, however, furnished 18 representatives ; Austria, I6; Great Britain, I I ; France, Io; United States, 9; Belgium and Russia, 6 each; Sweden and Switzerland, 3 each; Norway and Holland, 2 each; Spain, I; Brazil, I ; India, I ; Japan, I; Portugal, I ; Roumania, I. The meetings were held in the buildings of the Reichsrath, or Parliament, the large room set apart for the deliberations of the Congress being that of the Lower House of Representatives, and no little interest was taken by the foreign geologists in the names of the Members of Parliament inscribed on the backs of the seats. The door also was pointed out from which the great Chancellor emerges to launch his philippics against the contumacious opposition. But the genius loci inspired no flights of eloquence nor much disputatiousness among the geologists. The use of French as the language of discussion was no doubt one effective cause of silence on the part of many members who would otherwise only too readily have made themselves heard. Under such circumstances the Latin races have of course a considerable advantage over the Teutonic. One of the Berlin papers gave articulate expression to the complaint that in an audience nearly two-thirds of which were Germans, French should have been chosen, and great was the delight expressed by the German element in the Congress, when the Minister of Public Instruction, who officially welcomed the assembly, gave his eloquent and appropriate address in German. But by common consent, and with much good humour, though often with a disregard for the claims of grammar, idiom, and pronunciation that must have been infinitely ludicrous to the French-speaking members, the international official language was used throughout the proceedings.

The ostensible work of the Congress, which lasted nearly a week, may be divided into five parts. Of these the first in order of treatment and also of importance was the report of the Commission entrusted at the previous (Bologna) meeting with the preparation of a geological map of Europe. During the four years that have elapsed since the Congress determined to undertake this work, satisfactory progress with it has been made. The topographical outlines of the map have been completed and engraved, and the Commission were able to show upon the wall a mounted copy of the outline map. The materials necessary for filling in the geology have already been supplied for a large part of Europe, and it is expected that in the course of next year the work will be so far advanced that proofs in colour of many of the sheets of the map will be ready. There can be no doubt that the preparation of this great map is the most important and 
useful undertaking of the Congress. It is an eminently practical piece of work, with an attainable aim which unites the geologists of all European States in a common definite labour. The engraving and colouring of the map are carried on in Berlin. Judging from the present state of the engraving and from the scheme of colours adopted, we may confidently anticipate that the completed map will be a singularly clear and beautiful specimen of cartography, and will form a noble monument of international co-operation.

The second subject, to which the Congress devoted most of its time, was the unification of geological nomenclature. Reports had been received from different countries as to the names and classification of the various subdivisions of the geological record. But the wide differences of opinion expressed in these reports showed how little prospect there was that anything approaching to unanimity on such a subject would be reached by the Congress. It is to be feared, indeed, that the endeavour to unify stratigraphical nomenclature all over the world is more Utopian than practical. Nature is not everywhere uniform, and it seems almost puerile to strive after a uniformity of classification and terminology which has no counterpart among the rocks themselves. The Congress itself appeared to realise this, for it wisely postponed the consideration of all questions about which there could be any serious differences of opinion, and adopted only those propositions which nobody would controvert, and which hardly required an international congress to settle. Thus it was agreed that the Archæan rocks should be divided into sections according merely to petrographical characters and without expressing any opinion as to their relative age. The vexed question of the Cambrian and Silurian classification was postponed until the next Congress three years hence. A day was spent in discussing the position of the Permian system, with the result of leaving it for the present where it is usually placed. The subdivisions of the Mesozoic and Tertiary rocks were rapidly enumerated, but no discussion of them was possible in the time. In truth, it is difficult to see how any real effective discussion of these subjects can be attempted at the ordinary meetings of the Congress. The assembly is so large that probably only a fraction of the audience is really competent to express an opinion on the particular subject under debate. Some of the members who might contribute most valuable suggestions are deterred from so doing by their timidity in the use of the French language. To count the heads of so miscellaneous an audience and say that such and such are the decisions which it has voted can really carry little weight with the geologists of the world at large. Such at least was the opinion freely expressed among the members at Berlin. There was a very general feeling that the less the Congress attempts in the way of authoritative decision or legislation the more likely is it to carry on effectively other functions which are of far more general importance and usefulness.

Thirdly, the reading of communications on geological questions of general interest. Several good papers were read, but the thinned audience showed that this part of the programme was not very popular. There seemed to be no careful selection of papers, for some of those that were read hardly deserved a hearing before an international gathering of geologists. If this section of the proceedings is retained, it might be well to invite beforehand a few men of acknowledged reputation to give discourses, each on his own subject. There would be a strong desire to hear the masters of the science, and if three or four of them of different nationalities could be induced to accede to this proposal, there would be no need for catering among the rank and file of the assembly for papers to fill up the time.

Fourthly, an exhibition of geological maps, sections, specimens, and models. This collection was arranged in the room of the Bergakademie, and proved a source of much interest and instruction. The series of national geological surveys represented on the walls embraced a large part of Europe, and included some admirable examples of cartography. Among the specimens special attention was given to those exhibited by Mr. Reusch, showing Silurian fossils in the crystalline schists of Norway, those of Dr. Lehmann illustrating his work on metamorphism, the wonderful group of amphibian remains shown by Prof. Credner, the series of fossils brought by Dr. Torell from the Primordial and Lower Silurian rocks of Sweden, various collections from different localities among the Cretaceous rocks of Germany, and a remarkable assernblage of specimens of northern rocks and fossils from the drift of North Germany, exhibited by Dr. A. Remelé.

Fifthly, excursions to places of geological interest. At the close of the Congress a large number of the members proceeded in a special train to Potsdam, and spent a day seeing the sights of that royal demesne. Next morning they started for Thale in the Harz, whence, under the able guidance of Prof. Lossen, they were enabled to see some of the more interesting features connected with the protrusion of the granite and the metamorphism of the surrounding rocks, likewise the succession of stratified rocks up to the Chalk, thrown against the flanks of the Harz. From Thale the party travelled to Stassfurt, and descended into the salt mines, which were illuminated in its honour ; thence to Leipzig, where Prof. Credner acted the part of host and guide, and from which an interesting excursion was made into the Saxon granulite region.

But it is not by its formal and ostensible proceedings that the usefulness of the Congress is to be measured. There was a widespread feeling which constantly found audible expression, that the opportunities it afforded for personal intercourse and exchange of views were amply sufficient to justify its existence and to give assurance that it would long continue. The discussions among the animated groups in the corridors and ante-rooms were much more vivacious and probably quite as conclusive as those held in the large room. But most useful and enjoyable of all was the nightly Kneipe held in some beersaloon. There in a thick and pungent atmosphere of tobacco-smoke, amid the clattering of beer-jugs and shoutings for the Kellner, many of the foremost geologists of the Congress gathered together - stratigraphists, petrographers, palæontologists, mineralogists - full of scientific enthusiasm and good fellowship. Loud and long were the debates in these dim retreats. Tongues that had been shackled by French articulation now shook themselves free in the unrestrained vernacular of the country. There were no reporters of course, and no record remains of the discussions. But the recollection of these evenings will not soon pass away from the memory of those who took part in them. Men from distant parts of the world who had only known each other's writings, or at most had exchanged letters, were here brought face to face, and the foundations of many a pleasant and profitable friendship were doubtless laid.

Great praise is due to the organising Committee at Berlin, and especially to its indefatigable General Secretary, Herr Hauchcorne, for the arrangements made for the business of the Congress and the comfort of the visitors. Every detail seemed to have been carefully planned, and the result was evident in the smooth working of the whole machine. It was a great gratification to see the venerable Dr. Von Dechen presiding over such an assembly of geologists, and to hear his reminiscences of the early days of European geology. The bonhommie of the President, Prof. Beyrich, put everybody in good humour, and the active guidance of the former President, Prof. Capellini, contributed largely to the success of the Congress.

The next session of the Congress is to meet in London 
between August I 5 and September I 5, I888, and Messrs. Blanford, Geikie, Hughes, and Topley have been nominated a committee to make the necessary arrangements.

\section{BOTANICAL EXPLORATION OF THE} CHILIAN ANDES

$W^{E}$ are indebted to the Kew authorities for the accompanying extract from a letter dated August 2I, 1885, addressed to Sir Joseph Hooker by Dr. R. A. Philippi, the Professor of Botany at Santiago:-

"My son made in the summer during Iro days a voyage from Copiapo to the River Camarones, the actual boundary between Chili and Peru. He went first from Copiapo to Antofagasta de la Sierra $\left(26^{\circ} 5^{\prime}\right.$ lat., $27^{\circ} 20^{\prime}$ long., 3570 metres above the sea), where about 60 to roo people are living, and thence (nearly always on the high table-land of the desert at an elevation of 3500 to 4200 metres) to Huasco de Tarapacá, from whence he descended to the tamarugal. The voyage extended over 8 degrees of latitude. This high table-land is nearly a single bed of trachytic lava, on which are scattered a number of extinct volcanoes, three of which are higher than Chimborazo-viz. the Llullaillaco, 6500 metres (I was, twenty-one years ago, at its west foot); the Tumiza, 6540 ; and the Pular, 6500 metres. There are many large salt lakes, several entirely dry. The vegetation in this easterly part of the desert is not so scanty as in the westerly, visited formerly by me, perhaps owing to a slight influence of the trade wind; and the water-places are more numerous and nearer one to the other.

"The number of species of plants brought home exceeds 400 , of which half are not described. Amongst them is one Polylepis (without flowers), found only in one quebrada, and Pilostyles Berterii, a parasitic plant belonging to the same family as Rafflesia, found at the height of $3700 \mathrm{~m} . !-$ of course on an Adesmia. The three species of ferns are: Pellac ternifolia, Cheilanthes micropterus, and a beautiful Cincinnalis which seems to be new. The most numerous family is, of course, Synanthereæ, with $94 \mathrm{sp}$; Gramineæ bas 42 (among them a new species of Munroa); Leguminosæ, 28-29; Verbenaceæ, I5 ; Solanaceæ, 28 ; Chenopodiaceæ, I5. Amongst these plants nine or ten must form, in my opinion, new genera. Some are very curious, as a Verbenacea, which grows in small hemispherical tufts and has the aspect of a Synantherea, with sessile flowers and pappus. This pappus proved to be a deeply-divided calyx with long cilia. There is another genus which I took at first sight for a Tribulus. I hope that my age, my health, my eyes, and my time will allow me to draw up the generic diagnosis, at least, of these plants."

\section{KRAKATÃO}

THE publication of the first part of Verbeek's " Krakatao," which chiefly contained the history of the great eruption of 1883 , had raised many expectations regarding the promised description and discussion of the phenomena then observed. In his completed work, which contains 25 coloured drawings and 43 large and small maps, those expectations are fully realised. Immediately after the great outburst of August, I $88_{3}$, the Dutch Indian Government sent him to visit Krakatao and to investigate the causes and effects of this awful catastrophe, more sudden and destructive than the famous eruption of Vesuvius. The great facilities they placed at his disposal enabled him to do this in the most satisfactory manner, and the really beautiful character of his completed work reflects the greatest credit not only on the learned author, but on the zeal and public spirit of the Dutch-Indian Government, who have aided him in making so valuable a contribution to scientific knowledge. So much interest has been taken by the general public, as well as by men of science, in this remarkable eruption, that we feel certain they also will welcome this volume, since it is lucid in style and profusely illustrated. With an expression of his gratitude to various institutions and individuals who have rendered him valuable assistance, the author gives in the preface a list of the weights and measures, together with a summary of the most recent ideas that geological science has received from the Krakatão eruption.

Krakatã itself lies on the point of intersection of three fissures or crac'ss in the earth's crust, and from this position is naturally exposed to volcanic disturbances. The earthquake of September I, I880, which damaged the lighthouse on Java's First Point, probably affected the Sunda fissure and facilitated the entrance of greater quantities of water into the volcanic furnace underlying the Straits of Sunda. Accepting the theory that volcanic eruptions are caused by steam at high pressure, we have thus the probable explanation of the terrible outburst of 1883. From the observations of earthquakes in the Indian archipelago during the year 1883 , it appears that the eruption was neither preceded nor accompanied by heavy shocks. It is even far from certain that any trembling of the surface took place at the time, since the vibration of the air caused by the explosion was sufficient to shake houses and crack walls, and thus might easily have been mistaken for earthquakes. The author further treats of the ejected materials ; their thickness, which, on some parts of Krakataon, amount to 60 metres; their size, varying from bodies of one cubic metre to the finest dust; the velocity with which they were thrown out, which must have been considerably greater than that of projectiles from the heaviest rifled ordnance; the elevation which they reached has been calculated at 50 kilometres, or nearly six times the height of Mount Everest, the highest mountain of the world, and the ashes have fallen over an immense area. From investigations made at fifty different places regarding the thickness of the fallen ashes and also the change in the depth of the sea around Krakatao, M. Verbeek has calculated that at least 18 cubic kilometres of matter must have been ejected. To give an illustration: imagine a box of ashes as large as Hyde Park and as high as the dome of St. Paul's, a hundred such boxes will give an idea of the mass of matter thrown out by Krakatao in I 883 .

For three days after the eruption various ships to the westward found ashes falling on their decks; the names of these ships are given, as well as a map showing their exact position at the time. Mr. Verbeek believes that the finest particles, forced by the steam into the upper air, did not descend, but were carried westward by strong east winds, making twice the circuit of the earth and causing the phenomena observed at various places of a blue and green sun and moon. 'The passage of this cloud has been reported from islands and ships in the Pacific Ocean and its velocity must have been as great as that of a hurricane. After the steam and dust-cloud were dispersed over a wider area the beautiful red sunsets occurred, which were owing to the presence of such a large volume of aqueous vapour, while the blue and green colours of the celestial bodies were caused by the solid particles in the air.

The author goes on to elucidate the geology of Krakatá by two maps and four very instructive sections, showing its development during that number of periods. The first period was marked by the destruction of the great cone, probably 2000 metres high; during the second period the peak Rakata was formed by a lateral eruption, while in the third period two parasitic cones, Danau and Perbvewatan, were added, and these, by their successive eruptions, built up the island of Krakatao. In the fourth 